carriage; a clock of wondrous simplicity and accuracy, the motive power of which was a drop of water, a fresh drop always waiting ready to be picked up and to give its impulse to the returning arm of the cscapement; a goniometer, consisting solely of a block of wood with a straight cdge, and an upright wire with its end bent round so as to carry a cork with a second wire on which the crystal was fastened, and by which it was adjusted for measurement on Wollaston's method, the angle between two positions of the straight edge being found by the aid of a pair of compasses and determined by a continued fraction. These are a few only of the marrels of ingenuity which every one admitted to that interesting room will remem ber; and there were implements of observation fashioned out of the simplest materials-deal, cork, glass tube, wirc --by the hand of their inventor, rough to look at, but exact in their performance. Nor was there any man who better appreciated the elaborate mechanism of an important instrument; no one, for instance, who could make an afternoon at the Greenwich Observatory more interesting and suggestive alike to the instructed student and to the uninformed visitor.

Such was the work of Miller. Personally he was quiet, unobtrusive, but observant; retiring, almost shy, in his manner, but in the highest degree genial and full of cordiality when this curtain of instinctive restraint was drawn aside and you mct the man himself face to face.

$\mathrm{He}$ was a traveller. Impelled by his old master Whewell to the study of German as necessary to a mineralogist, he spent many a long vacation in the German and Tyrolese haunts of the mineralogist, and lost no opportunity of exchanging speech and therewith winning the esteem of the masters of his science on the Continent. Most of those contemporaries he survived. Mitscheriich, Gauss (who paid him the just tribute of complimenting him with having "exactly hit the nail on the head" in his Crystallography), Dove, Gustav Rose, Haidinger, Breithaupt, Wöhler, Sartorius von Waltershausen--names many of them but yesterday of living workers, were those of silent men before Miller's grave was closed, but they and Miller had in life been united by esteem and regard, and in some cases by warm friendship.

Of the travels which thus brought friendships and new scenes home to him, and in which he acquired valuable additions to the mineral collection at Cambridge, he had other pleasant records in the sketch-books which his constant companion, Mrs. Miller, filled as thcy journeyed.

'Those who know the broad strath of the Towey above Llandilo in Carmarthenshire will remember, near its heacl, in the neighbourhood of Llandovery, a pretty gentleman's seat named Velindra. This was Miller's birthplace. Here his father, Captain Francis Miller, had settled towarcls the close of the last century, after fighting as an officer in the English army throughout the American WVar of Independence, and after losing a good estate which he possessed in the Boston Government, and which he never recovered. He too came of a fighting family, and doubtless something of the independence, the rescrve and gentlemanly courtesy of the crystallographer came to him through this inheritance.

The valuable collection of minerals at Cambridge was largely the fruit of Prcf. Miller's long-vacation rambles. The addition to it of the collection of Mr. Brooke, presented by his son, the late Mr. Charles Brooke, was an appropriate gift, considering the illustrations Miller had so copiously drawn from that collection for the important treatise on Mineralogy, to which he modestly gave the title of an edition of Phillips' "Nineralogy," by Mr. Brooke and bimself: the rcal authorship of all that made the book invaluable to the true mineralogist being his whose name stood last, though for ever greatest, on the title page.

Some of his later years were devoted to arranging in the New Museum at Cambridge the collection he had done so much to form. He did not live to make a catalogue of it, though Mr. Lewis, who during Prof. Miller's illness was intrusted with the duty of acting for him, has commenced the laborious work of a register. as a prelininary to a catalogue.

There have been rumours that a change would be made in the character of the chair before the appointment of a successor to Prof. Miller. Considering that but for the two mineralogical chairs at the two great universitics of England the study of crystallography otherwise than as an almost childish adjunct to popular lectures on mincralogy would have been extinguished in England, it may be worth while to urge that the signifi. cance of crystallographic structure as a key to great physical problems, and probably too, when the chemists have awakened to the fact, as a key to some of the newest problems in chemistry, gives to crystallography a very considerable claim for recognition among the subjects taught in the university that produced the greatest crystallographer of our time. N.STOREY MASKELYNE

\section{PAUL BROCA}

WE regret extremely to have to announce the death of this distinguished physician and anthropologist, which took place suddenly at Paris on Thursday last. He had attended a meeting of the Senate, of which he had lately been elected a member, and died during the night in consequence of the rupture of an aneurism. He was fifty-six years of age, born at St. Foy, in the Gironde, educated for the medical profession, and became Professor of Surgical Pathology at Paris. He soon acquired a high reputation by his researches in cerebral pathology, and continued to devote himself with great zeal to hospital work and clinical teaching to the last; but it is ehiefiy in consequence of his having taken up the subject of anthropology that he has obtained a world-wide fame, and occupied a position which it will indeed be difficult to fill up.

Twenty years ago the science of physical or anatomical anthropology was in its infancy, and all investigations were at variance even as to the methods to be pursued in its cultivation. Broca devoted many years of unceasing activity in endeavouring to define, systematise, and perfect these methods. The thoroughness and energy with which he threw himself into any research which he indertook were marvellous, and only equalled by the clearness and facility of expression with which he communicated his results to others. His series of essays on various subjects connected with craniometry, published in successive numbers of the Mémoires of the Sociéte d'Anthropologie of Paris, and the Revuce which he founded, and his "Instructions craniologiques et craniométriques," with the introduction of numerous neat and happily chosen terms for descriptive processes, have made an immense advance in the progress of the science.

Happily Broca's perfert simplicity and amiability of character, his pure love of science for its own sake, and his readiness to help those engaged in pursuits similar to his own, have inspired with enthusiasm most of those who came in contact with him; and he has created at Paris a school which it is to be hoped will carry on the work which he inaugurated. We may take occasion to notice his scientific work in greater detail in an carly number.

THE UNITED STATES WEATHER MAPS, SEPTEMBIER, 1878

$\mathrm{I}$ the description of the Lnited States Weather Maps for August, 1878, attention was drawn to the fact (vol. xxii. p. 36) that in that month atmospheric pressure was under the normal over a broad belt going halfway round the globe, extending from the Rocky MIoun. tains across the United States, the Atlantic, Europe, and thence into Asia as far as the valley of the Lena, and the 
bearing of this abnormal distribution of the pressure on the temperature, winds, and rainfall of this large and important part of the globe was adverted to. In the September following, the U.S. Weather Map for which appears with this notice, great and radical changes in the distribution of pressure took place-such as a change from a large defect from the normal pressure to a large excess above it in the New England States, South Britain, Central Europe, South Africa, and New Zealand; and on the other hand, a change equally striking from a large excess above the normal to a large defect from it over the West India Islands, South Greenland, Iceland, North Britain, and the whole of Southern Asia from the Bay of Bengal to Japan. As it is still premature to speculate on the causes of these enormous changes in the distribution of the mass of the earth's atmosphere and the still more enormous forces called into play in effecting them, we must content ourselves with stating them a little more in detail, and drawing attention to some of the more immediate and striking climatic consequences which followed in their train.

In North America pressure fell most below the normal about Lake Winnipeg, and southwards over the region traversed by the upper tributaries of the Missouri and Platte Rivers. This region of low pressure was extended, though in a less pronounced form, to the south-east, deepening again, however, on approaching Florida, to 0.090 inch, the greatest depression below the normal in the Bahamas. Over the Gulf States and westward through Texas and California, pressure was above the average; and to the north-eastward of the region where pressure was low it rose gradually, till in the Gulf of St. Lawrence it stood at O.I33 inch in excess of the average.

This high pressure extended across the Atlantic, and thence overspread Ireland, England, the northern half of France, Germany, all Russia except the extreme south near the Black Sea, and on into Siberia as far as the valley of the Tobol. As already stated, the southern half of Africa and the whole of New Zealand had a pressure considerably above their normal, the excess in the northern island of New Zealand being about $O^{\circ} 150$ inch.

To the north of the European belt of abnormally high pressure there was a widespread region of low pressure including South Greenland, Scotland, Denmark, and Scandinavia, the centre of greatest depression being 0.209 inch below the normal in the north-east of Iceland. On the other side of the European belt of high pressure lay a most extensive stretch of low pressure covering the Spanish peninsula and the rest of Southern Europe; the north of Africa, all Asia, except Siberia to westward of the Tobol River and a small patch including the Lower Amur, the East India Islands, and the whole of Australia. In this widespread region centres of still deeper depression were formed in Italy, the Upper Obi, Western India, Southern China, and the south-eastern division of Australia, the depressiors below the normal pressures of these five regions being respectively $0^{\circ} I_{33}$ inch, $0^{\circ}{ }_{4} 6$ inch, 0.084 inch, 0070 inch, and 0.136 inch. The sharpness with which the regions were marked off will be seen from the statements that in their rclations to the normals pressures showed differences of a fall of $0^{\circ} 342$ inch from Nova Scotia to Bernfiord in Iceland, 0.329 inch of a rise from Bernfiord to Cork, and $0^{\circ} 153$ inch of a fall from Cork to Rome, and o'29o inch of a rise from near Melbourne to Napier in New Zealand.

In the United States, temperature was under the average on the western side of the area of low pressure, the deficiency from long. $98^{\circ} \mathrm{W}$. to the Rocky Mountains being from $I^{\circ} \cdot 5$ to $3^{\circ} \circ$. This low temperature extended far to northward, the deficiency from the normal amounting to 4.5 at York Factory, Hudson Bay. In the region of high pressure which overspread the New England States the rainfall was small, and temperature from $I^{\circ} .5$ to $3^{\circ} .5$ above the normal. On advancing, however, to the north-east, temperature fell to near the average in Newfoundland, which lay just on the western outskirts of the great barometric depression which had its centre near the northeast of Iceland. Greenland was completely enveloped in the western division of this depression, and there it will be seen that winds were northerly and easterly, and temperature consequently fell to $4^{\circ} \circ \mathrm{O}$ below the normal. On the other hand, Scotland occupied the south-eastern segment of the barometric depression, and there, consequently, winds were west-south-westerly; temperature was from $I^{\circ} \circ$ to $2^{\circ} \cdot 0$ above the average; and the rainfall in the west of the country from 40 to 1 Io per cent. above the average; whereas near the east coast it was about, or rather slightly under, the average. Thus in Scotland the distribution of the rainfall of September was the reverse of what prevailed in August, the weather in the latter month being fine and dry in; the west, but wet and backward in the east. These differences of weather were occasioned by the circumstance that in August the centre of greatest barometric depression was to the south-west of Jreland, thus resulting in rain-bringing easterly winds in Scotland with the distribution of the rainfall stated above; whereas in September the centre of the barometric depression was near Iceland, thus resulting in rain-bringing westerly winds in Scotland, and consequently unfavourable weather in the west, but favourable weather in the east for the ingathering of the harvest.

Temperature was about the average in England, slightly under it in France and Western Switzerland, but above the average over the whole of the rest of Europe, and eastward into Asia as far as the area of high pressure extended. The greatest excess of temperature over this extensive region occurred in the great plains of the Danube and the Dnieper, where it amounted to from $4^{\circ} \circ$ to $5^{\circ} 6$. In Italy the excess was small, and in Sicily temperature even fell $\mathrm{I}_{4}^{\circ} 4$ below the average, and this area of low temperature was continued to the north-west through France. Another breadth of low temperature, falling however nowhere lower than $2^{\circ} \circ$ below the normal, extended from the Caspian Sea as far to the north-east as the head-waters of the Yenisei, in other words over the western side of the barometric depression which overspread this part of Siberia. To the eastward of the Yenisei temperature was above the average, but only slightly so, nowhere exceeding $2^{\circ} \circ$.

The greatest barometric depression in Australia lay off the coast south of Melbourne, and in accordance therewith, keeping in view the law of the winds of the southern hemisphere, the prevailing winds were N.E. and N. at Gabo Island and Melbourne, and N.W. and W. at Sandhurst and Portland; in other words, with the distribution of pressure described, equatorial winds blew over this part of Australia, and the temperature rose at Wilson's Promontory to $3^{\circ} .2$ above the normal; and the winds being land winds, the rainfall, particularly at places in the interior, was considerably below the average. In New Zealand pressure was not only absolutely higher in the north than in the south, but also much higher relatively to the normals, and it was also higher in the west than in the east. Under this distribution of the pressure and the strong equatorial winds resulting therefrom, temperature rose above the normal over the whole of New Zealand, the excess being nearly $4^{\circ} \circ$ at Dunedin, Christchurch, and Napier.

\section{NOTES}

IT was scarcely to be expected that the debate last Friday in the House of Commons on Mr. Roundell's motion for the complete abolition of the clerical headships and fellowships at Oxford and Cambridge should have had any other ending than it had. The Government thought it scarcely fair to the University Com- 